\title{
A NARRATIVE INQUIRY OF STUDENTS TEACHERS IDENTITY CONSTRUCTION THROUGH TEACHING PRACTICUM: VOICES FROM SECONDARY SCHOOL CLASSROOM IN INDONESIA
}

\author{
Devi Apriliani \\ apriliadevi224@gmail.com \\ Faculty of Teachers Training and Education \\ Universitas Singaperbangsa Karawang, Karawang, West Java, Indonesia
}

\begin{abstract}
This study aims to explore the student teachers' experience while conducting a teaching practicum. The study identified how three student teachers construct their teacher identity. This study also explores the proper way that they do to manage the classroom in the placement school. I examined the narratives from three student teachers by sharing stories of their teaching practicum in a secondary school in Indonesia for about a month. This study uses in-depth online interviews, reflective journals, and photovoice to collect the data. All the data was collected online by using the WhatsApp platform. The results suggest that teaching practicum can be a way to construct student teachers' professional identities and lead them to deal with the situation in the classroom during the teaching practicum. Exploring their way of managing classrooms is used to measure how they can apply what they get on the campus into the real-classroom. Moreover, preceding teaching experience and good relationships with members of the school are essential to carry them out from teaching practicum. These findings have implications to be a reflection for both teacher and student teachers' in the classroom context.
\end{abstract}

Keywords: Student Teachers, Teachers' Identity, Teaching Practicum, Classroom Management, Narrative Inquiry

DOI: https://doi.org/10.31943/wej.v4i2.108

\section{INTRODUCTION}

Teaching practicum has become an essential stage for student teachers. It prepares student teachers to provide professional teachers. Although English has become an international language, it does not make teaching the English language easier, especially teaching secondary school students. As an English student teacher, the students are required to be able to teach well and gain excellent experience in teaching during teaching practicum. Nevertheless, most of the student teachers are not ready to teach in the class. It is in line with March (2010) from Stuart and Thurlow (2000) that the student teachers are not quite prepared to get a real classroom environment. From the previous research by Alghamdy (2018), most of the student teachers complain about the regulation that they have to do a teaching practice but still studying some courses at the campus at the same time. They feel that it was the hardest thing to do. 
There are some benefits that the student teachers might get. The student teachers will gain more experience in teaching, and they will learn how to deal with the situation in the classroom. Teaching practicum also will be able to increase their confidence and social skills. Yet, from the American Association of Colleges for Teacher Education (1991) some researchers found that teachers guiding are giving some effect on student teachers. A similar point of view is demonstrated by Mason (2013), who said that many teachers are influential if they provide the students chance to be more active in their teaching practicum. Some of the student teachers also claimed that they need to get more practice on how to manage and control the class because it is an essential skill for the teacher (Alghamdy, 2018).

Teachers' identity stands at the center of teaching professionalism. Teachers' identity describes how the teachers seem to understand themselves as a teacher. The student teachers need to construct their own idea of what and how they should be. It is in line with Sachs (2005) that teacher identity helps the student teachers to construct their own ideas of how they should behave in society through experience and the sense of that experience. The experience can be obtained through their teaching practicum. In education, the concept of teachers' identity appeared in the 1980s (e.g., Cherryholmes, 1980) as studying teaching and teacher education. Coldron \& Smith (1999) stated that teachers' identity reflects the dynamic interaction between social and individual contexts.

Teaching practicum leads the student teachers to construct their identities by positioning themselves as particular types of teachers. It can be a chance for the student teachers to test are being a teacher is really suitable for them (Trent, 2013). During the teaching practicum, they will collaborate with their mentoring teacher and supervisors as the stakeholders. The stakeholders, mentoring teacher, and supervisors can assist the student teachers to better understand their responsibilities as a teacher (Grudnoff, 2011). Also, Davies et al. argue that teaching practicum plays a vital role in elaborating on the personal competence of student teachers. The different concepts of teaching in the University class and real-life, and the roles of teachers, make teaching practicum feasible to serve as an opportunity to construct the student teachers' professional identities (Smagorinsky et al. 2004).

Narrative Inquiry has been seen as an approach to study identity (Leigh, 2019). Narratives are an effective tool to understand people's actions, experiences, and identities. Narratives are used to understand the experience through threedimensional inquiry space. There are the temporal, the social, and the spatial (Clandinin \& Caine, 2008). These space include a reflection on the past, present and future experience of the participant; the thought and emotion participant to themselves and other; and the place of the participant live. All of the spaces are stay in people's lives. The narrative inquiry will describe the stories of the student teachers while they do the teaching practicum. It discovers how they feel and how they act as a teacher in the class. It is also telling how they view themselves as a teacher and how they can construct their teacher identity through teaching practicum.

A few recent study that reports on the research of identity construction in Hong Kong, such as stated by Trent (2018) and Trent (2013). They conducted some research for the student teachers in the final year of B. Ed. Program in Hong 


\section{Devi Apriliani \\ A NARRATIVE INQUIRY OF STUDENTS TEACHERS IDENTITY CONSTRUCTION THROUGH TEACHING PRACTICUM: VOICES FROM SECONDARY SCHOOL CLASSROOM IN INDONESIA}

Kong. However, this study tries to research in a different place. Three student teachers who had carried out a teaching practicum in a secondary school in Indonesia are involved as participants in this research. Also, this study adds a theme, i.e., student teachers in classroom management. In this research, I documented and analyzed how the student language teachers constructed their identity through their storied experiences while carrying a teaching practicum. In addition, this study also explores the proper way that student teachers choose to manage their classrooms.

This study reports on a narrative of the student teachers' experience during their teaching practicum. This study contributes to advancing insight on some student teachers' identity construction through their teaching practicum. The result of this study expected to become a reference both for teacher and student teachers to increase their teaching professionally. Also, get them to realize of how to be a teacher and how they should act in the classroom.

\section{LITERATURE REVIEW}

Teachers' identity covered a sense of how to be a professional teacher. As stated by Sach (2010), teachers' identity is the sense of how to be, act and understand themselves as a teacher. Teng (2019), cited from Korthagen \& Vasalos (2005), argue that teachers' identity refers to what it means to be a teacher. Bullough (1997:21) stated that teachers' identity is basic for meaning-making and decision making. Mockler (2011) claims that teacher identity comprises in three domains. There are personal experiences, professional context, and the external political environment. The external political environment includes their attitude and understanding of everything about education that they got from any media and the government policy about education and their profession as a teacher.

Teaching practicum is a teaching training program that provides students to change their knowledge to the real-life in teaching (Chimhenga, 2017; Saban \& Cocklar, 2013). This program can be used to bridge the gap between what they already learned in the class and the reality of teaching in the school (Sulistiyo U. et al. (2017); Darling-Hammond, 2006). connect the student teachers' theoretical and practical experiences (Yost, Sentner \& Forlenza-Bailey, 2000). Turner and Fattu (1993) argue that someone who had practice in teaching can perform better in their fieldwork than they who had none. Consequently, it is essential to place the student teachers in a place where they can gain a lot of experience in teaching. Teaching practicum provides a lot of experience for student teachers. It is in line with Brock \& Grady (1998), teaching practicum gives space for student teachers to develop their professional identity and the essential things for meaningful teaching and learning. Moreover, negative or positive mentorship influences them in constructing their teaching identities. Mentoring teacher's expectations can give the student teachers freedom and chance to be more active, creative, and innovative when they are teaching in the class (Mason, 2013).

Wright stated, "Classroom management is the central element of every teacher's daily professional experience," including managing space, time, engagement, and participant (2005). Based on that, the teachers are required to be able to combine all the components. The teacher has to be able to choose the best technique and strategy in teaching, also inspire and motivate the learners (Korkut, 2017). 
Teaching practicum intended to provide student teachers the opportunity to construct and reconstruct their professional practice in the real classroom by guidance (Wallance, 1991). Discussing student teachers' obstacles in managing classroom, Monroe et al. argue that through collaborative teaching practicum program and school placement, the student teachers will get knowledge about classroom management and its preventive strategy. Furthermore, they have a chance to get practice with guidance (2010). Indeed, they get the chance through teaching practicum programs (Ragawanti, 2015).

Recent studies on teacher identity and teaching practicum, Trent (2013) show that identity work is an important thing in student teachers' experience of a teaching practicum. Teaching practicum makes the student teachers understand in positioning themselves as a teacher. It also creates their understanding of what they should act and deal with the situation in the school. Meanwhile, Schepens et al. (2009) show that every student teachers have to be prepared when they are studying in teacher education. Yet, they are not quite prepared. Wenger's (1998) stated that engagement, imagination, and alignment as the basis of constructing identity. Student teachers' identities are temporal and ongoing. It means that it can be changed during the time (p.154). Studies related to student teachers' perception of teaching practicum came from (Williams, 1989; Divins, 1991; Wilson \& Cameron, 1994). They said that the quality of where the student-teacher does teaching practicum influence their teaching practice.

Moreover, Kelly (1993) found that the student teachers' conceptions of teaching are increased through teaching practicum. It reveals that besides theories, field experiences are also needed. Moreover, Korkut (2017) investigated how student teachers manage their classes during their teaching practicum differently with in-service teachers. This study found that both student teachers and inservice teachers have their own way of managing the class. In this present study, I tried to investigates how the student teachers' perception of identity construction and classroom management during teaching practicum in Indonesia.

\section{RESEARCH METHODOLOGY \\ Research Method}

This study aims at exploring how student teachers construct their identity through teaching practicum. It reveals student teachers in perceiving teaching practicum. Therefore, the research design of this study is narrative inquiry. Narrative inquiry is a way of understanding and inquiring into the experience through "a collaboration between researcher and participants, over time, in a place or series of places, and in social interaction with milieus" (Clandinin and Connelly, 2000: 20). The narrative inquiry is considered being a research tool that provide information about someone's act (Teng, 2019; Barkhuizen et al., 2014).

\section{Participants}

This study uses the WhatsApp platform to gather all the data from the participants. Before the research began, I asked my friends in the teaching practicum group to participate in my research. Three participants, Rahma, Asri, and Ola, are agreed to be the participants of this research. The participants are student teachers in the final year who enrolled teaching practicum in one of Junior 
High School for about a month. The table below shows the participants' demographic information.

Table 1 Participants' demographic information

\begin{tabular}{|c|c|c|c|c|c|}
\hline Participants & Gender & Age & $\begin{array}{c}\text { Linguistic } \\
\text { Background }\end{array}$ & $\begin{array}{c}\text { Educational } \\
\text { Background }\end{array}$ & $\begin{array}{c}\text { Length of English } \\
\text { learning experience } \\
\text { (Approximately) }\end{array}$ \\
\hline Rahma & Female & 22 & Indonesian & $\begin{array}{c}\text { Undergraduate } \\
\text { Student } \\
\text { Javanese }\end{array}$ & 12 years \\
\hline Asri & Female & 22 & $\begin{array}{c}\text { Indonesian } \\
\text { Sundanese }\end{array}$ & $\begin{array}{c}\text { Undergraduate } \\
\text { Student }\end{array}$ & 12 years \\
\hline Ola & Female & 22 & Indonesian & $\begin{array}{c}\text { Undergraduate } \\
\text { Student }\end{array}$ & 12 years \\
& & Minangnese & . & \\
\hline
\end{tabular}

As the study focused on exploring identity construction and how they manage their classroom, three student teachers who enrolled in teaching practicum selected as the participant of this study. This narrative explored how three student teachers put themselves as a teacher in the classroom.

\section{Data Collection and Analysis}

The data were collected through interviews, reflective journals, and photovoice. Seeing the pandemic of the Corona Virus, the interview was done by using the WhatsApp platform. In this online interview, the participants are asked to share their experience in their teaching practicum. I will then transcribe all of this interview. Besides, reflective journals and photovoice are also used in this study. The reflective journal used to know how the teaching and learning process in the student teachers' minds. At the same time, photovoice is using to show when the teaching and learning process is running. It is also used as documentation and evidence that they have accomplished teaching practicum. Furthermore, thematic analysis from Braun and Clarke (2006) used to analyze the data that I have been collected.

\section{FINDING AND DISCUSSION}

Drawing on the data from an online interview, reflective journal, and photovoice, main themes were identified (1) teaching practicum as the activity to construct student teachers' identity and (2) student teachers managing classroom on teaching practicum. These themes reflect the construction of student teachers' identity questions of the study. 
Wiralodra English Journal (WEJ)

Vol 4 No 2 September 2020

\title{
Finding
}

Teaching Practicum as the Activity to Construct Student Teachers Identity

Choosing English Department in the Faculty of Teachers Training and Education can be a struggle for some student teachers. Because some of them do not desire to be a teacher. In the beginning, some of them are choosing this major just to get the English skill. As Rahma and Ola stated:

\begin{abstract}
Extract 1
To be honest, when I choose the major, it is kind of confusing to me. So, I choose the English department because the only strongest skill that I have is English, and hopefully, I can pass the S1 with easily. Even though I don't know after graduated what I am will be. Fortunately, during the learning process, the lecturer rebuilds me by giving me motivation about the benefits of being a teacher. So I decided to be a teacher after I graduated from Unsika, InsyaAllah. (Rahma, online interview, 18 May 2020)

Extract 2

I only wanted to learn English, and I didn't think it will become a teacher if its education, but it's okay for now. (Ola, online interview, 18 May 2020)
\end{abstract}

In the beginning, both of them are doubtful to choose this major. However, after spending several semesters, they start to be ready being a teacher, especially Rahma. Rahma sensed her identity as a teacher. Motivating by others is succeed in making Rahma believe that she has to be a teacher after graduating from her University. Also, Asri felt that the same motivation and inspiration from her environment had a great role in her decision to choose a teacher as her future career.

She expresses:

Extract 3

I had a desire to become a teacher when I was in 6 grade in elementary school. I really admire the teacher, who became my homeroom teacher. And also, indeed, the support of my family for my decision to be a teacher. Because many of my family are experienced as educators, so, I'm more motivated by stories from my family. (Asri, online interview, 5 June 2020)

Yet, it is not always running well. They got some problems for the first time her teaching in the placement school. As Rahma commented:

Extract 4 (Photovoice) 

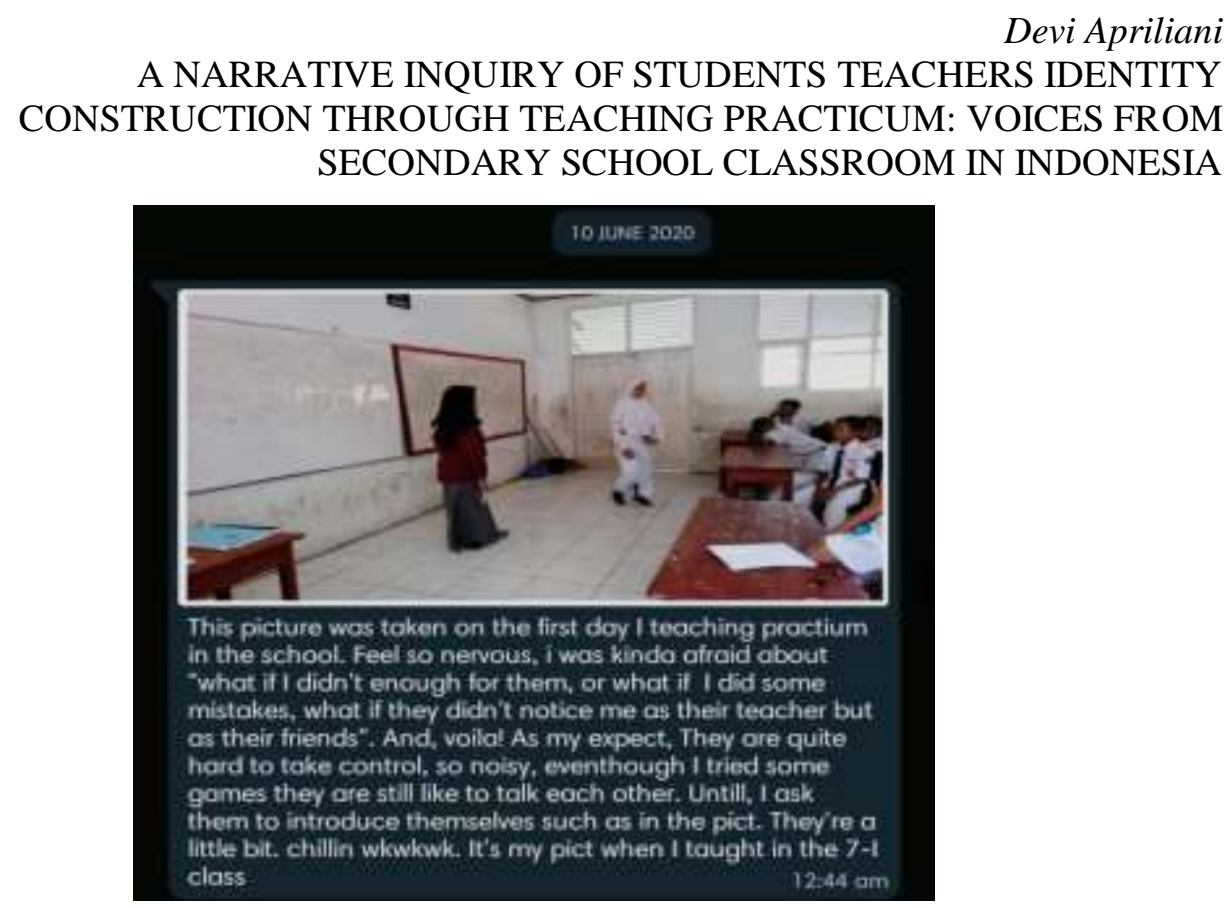

Figure 1 Rahma, photovoice, 10 June 2020

Teaching for the first time is always be a struggle. We have to do our best to give them a great first impression. Rahma shows that she was not confident in the first time teaching in the class. Teaching students, especially teenagers, are never easy. As a teacher, we have to understand our students. We have to be patient, treat them like we are their friends but still make them respecting us as their teacher. When teaching and learning process running, our duty is not just to convey the material but also to motivate them to learn.

During teaching practicum, student teachers encountered stakeholders, the mentoring teacher, and supervisor, who helped them pass this teaching practicum as well. As Ola stated:

\section{Extract 5}

My mentoring teacher was very helpful and kind when I was in teaching practicum. He helped and gave us suggestions to one of my friends and me.

(Ola, online interview, 4 June 2020)

The good stakeholders, mentoring teacher, and supervisor was really helped the student teachers to pass this teaching practicum. Then, through this teaching practicum, the student teachers' perception of being a teacher is changed. Also, their identity starts to construct. They stated:

Extract 6

Being a teacher is a precious job and a job that full responsibility because we create/build students' knowledge, skill, etc. before they really find out what they want to be. What the teachers taught will decide the students in the future. (Rahma, online interview, 18 May 2020)

Extract 7

When I become a teacher, I must be a good educator, especially with how I can make the students interested in me with the lesson, and I have to make children become comfortable learning with me, especially in learning English. (Asri, online interview, 4 June 2020)

The teacher was a noble job. Their teacher identity has emerged through teaching practicum. It brings their view of a teacher deeply. Also, teaching practicum realized what they have to do, to act, and how they should positioning themself as a teacher. 
Teaching practicum hit Ola to realize that being a teacher is never be easy, but it is a great job for everyone. A teacher should have some positive impacts on the students. Perceiving that being a teacher is not her passion, Ola stated:

Extract 8

I already told you that being a teacher is hard for me because I have to deal with different types of students. (Ola, online interview, 4 June 2020)

However, one month after taking the teaching practicum program, Ola had not thought about being a teacher as her job. Her use of "I already told you" showed that she is really sure of her statement. It showed that although she had accomplished her teaching practicum, Ola still doubtful to be a teacher.

\section{Student Teacher Managing Classroom on Teaching Practicum}

During her teaching practicum, Rahma has enjoyed her teaching in the class. Even she found some obstacles during her teaching in the placement school. She said:

Extract 9

I was really really enjoying those times with them even though not every student listening to my explanation. (Rahma, online interview, 18 May 2020)

The use of "really really" showed that Rahma loves her teaching in the placement school. As a teacher, Rahma guesses how to make teaching and learning processes still running well in the lack of facilities. She stated:

Extract 10

For the first time, I was kind of confuse and let it be. And then, I ask the official teacher, named Ms. Mutia, about how to make students follow our instructions, then she tells me that I have to choose the "bossy" students in that class to answer my question or maybe write the example of the material in the whiteboard, so the other will follow it. About the facilities, I only give the student's paper task and some of the media learning such as things in the class. (Rahma, online interview, 18 May 2020)

Asking her mentoring teacher was a good idea. As a seasoned teacher, Rahma's mentoring teacher was more understanding of how to deal with all of the students in the class.

Extract 11

How I organized the class is I became a student-teacher that can make them open up more to me, such as I was trying to give them a good role, so they motivated me to learn English. In my opinion, we should start with ourselves first, and the rest will follow, as long as it is a good way. (Ola, online interview, 19 May 2020)

\section{Extract 12}

for managed students in the classroom when I first met that, I used how to use games and also songs at the beginning of learning and before learning, I always invited students to be more active in speaking, so I invited them to talk about the material that had been prepared and which would be in doing it. The point must be to grab the hearts and attention of students first so that in the future, it can be easier to discipline them. (Asri, online interview, 4 June 2020)

\section{Extract 13}

I apply PowerPoint also in the process of delivering related material, so students are more focused on the material to be discussed (Asri, online interview, 4 June 2020)

By giving them chances to explore their expression, Ola could build a good atmosphere in the class and make the students motivated to learn. Moreover, using games and technology, e.g., PowerPoint, are adequate to make the student more interested to learn. 


\section{Devi Apriliani \\ A NARRATIVE INQUIRY OF STUDENTS TEACHERS IDENTITY CONSTRUCTION THROUGH TEACHING PRACTICUM: VOICES FROM SECONDARY SCHOOL CLASSROOM IN INDONESIA}

Furthermore, Rahma also carries out some activities and seating arrangement that make them more enthusiastic about learning English. She prepared four activities below:

Extract 14

Table 2 Rahma, reflective journal, 22 March 2020

\begin{tabular}{|c|c|}
\hline Planned seating arrangements & Descriptions of activities and seating arrangements. \\
\hline Activity 1 & \multirow[b]{2}{*}{$\begin{array}{l}\text { Debate } \\
\text { I will use this seat to make debate activities. The class } \\
\text { will be divided into two groups or two sides; one of } \\
\text { them is affirmative and contradictory. The teachers will } \\
\text { give the hottest issue that happened, and both of them } \\
\text { will argue their opinions, and then the contra group will } \\
\text { be refuted and so on. And the teacher will be the } \\
\text { moderator at this current time. I choose this seat into } \\
\text { debate activities because this seat facilitates the students } \\
\text { feel free to speak up. So, students' do not worry about } \\
\text { feeling under the intimidation of the teacher's. }\end{array}$} \\
\hline & \\
\hline Activity 2 & \multirow[b]{2}{*}{$\begin{array}{l}\text { Storytelling/Short story/Describe yourself } \\
\text { I will use storytelling, or student could make a short } \\
\text { story about anything based on their imagination, or } \\
\text { maybe describing themselves as speaking activities. } \\
\text { Students' can express themselves or maybe talk about } \\
\text { stories in front of their friends, the same as a debate. In } \\
\text { this case, students feel free to speak up about anything. } \\
\text { Of course, the teachers keep controlling what they are } \\
\text { talking about. This seat allows students' to make a "U" } \\
\text { letter at the class. I choose this seat as storytelling, short } \\
\text { story, or maybe describing activities because every } \\
\text { student' has only focused on their friends who are } \\
\text { talking in front of them. So, there is no students' talk or } \\
\text { chit-chat each other. }\end{array}$} \\
\hline$g$ & \\
\hline Activity 3 & \multirow[b]{2}{*}{$\begin{array}{l}\text { Poem/Poetry } \\
\text { At this seat as teacher's, I will use the seat to combine } \\
\text { students' speaking skill with art. In this case, I use poem } \\
\text { or poetry activities, which is the classroom that looks } \\
\text { like there is an audience who watch their friend's talk in } \\
\text { front of the class. Students speak up about the theme that } \\
\text { teachers give, and then the other students' watching, } \\
\text { their friend's performance. Also, the poem or poetry } \\
\text { activities did not make English learning bored. There is } \\
\text { challenging that students need to pass. }\end{array}$} \\
\hline 0 & \\
\hline Activity 4 & \multirow[b]{2}{*}{$\begin{array}{l}\text { Presentation } \\
\text { I think this seat will be fit on presentation activities. } \\
\text { These activities allow students to speak formally about } \\
\text { the material that they already prepared. And, other } \\
\text { students look at their friend's performance. A half square } \\
\text { shape helps another student' to learn with fun, they can } \\
\text { discuss, and everyone will pay attention to the presenter. } \\
\text { Also, this seat can allow the presenter to ask, point the } \\
\text { audience. }\end{array}$} \\
\hline 0 & \\
\hline
\end{tabular}

The activities planning was very beneficial. It was useful for every teacher to create a new atmosphere in the class. It is also helpful to urge the students to make them more active and be brave in expressing something or give their statement in 
front of the class. Selecting the right activity and seating arrangement will have a big impact on the students. It will support the learning development of the students.

\section{Discussion}

This narrative inquiry showed that teaching practicum could affect student teachers' identity. Although not all of the student teachers that accomplished this program was really constructing their teacher identity, as Ola experienced. After she accomplished her teaching practicum, she realizes what a teacher has to do and to act, but it does not change her perception that she has to be a teacher in the future. Ola still thinks that she does not want to be a teacher.

The stories of their experience served as a narrative site through which their identity as a student-teacher was shaped and reshaped in relation to their feelings and interaction in the social context (Clandinin \& Connely, 2000). It reveals that teachers' identity was not only linked to previous experience as a student-teacher on the campus but also their experience and socio-relationship with others during teaching practicum. This experience, including the obstacles that they found during teaching practicum, happened in the placement school.

Previous teaching experience influences their performance on teaching practicum. Asri is already teaching some students before this teaching practicum takes place. She performs better on managing her class and organizes her students and task in the class than who had none, such as Ola (Turner \& Fattu, 1993). It shows that preceding teaching experience influencing teaching performance.

Not only preceding teaching experience, the good relationship with the mentoring teacher and supervisor also essential. A good relationship helps the student-teacher in carrying out teaching practicum. Fortunately, during teaching practicum, they have a good relationship. The mentoring teacher and supervisors give them suggestions on what they should act and organize the students in the class. It means that the role of their mentoring teacher and supervisor are important in constructing their identities (Mason, 2013).

Related to Korkut (2017), who stated that classroom management is not only about how to control the class but also how the teacher can inspire and motivate the students, this study reveals that the student teachers can perform adequately in this teaching practicum. They can control the class, as well. They also can motivate the students. Like Asri and Ola do, they use PowerPoint to support the learning and make the students more enthusiastic whereas Rahma works better. She gives the students motivation before the teaching and learning process occurs (see extract 5 on Rahma story).

\section{CONCLUSION AND SUGGESTION}

The findings of this study show that the teaching practicum program helps three student teachers to construct their professional identity. Also, this program enriches their literacy regarding classroom management. Some struggles that they found during this program hit them used to face and control the situation and also themselves. Then, when they start teaching in one day, they will easier to control everything. Moreover, the suggestions from both mentoring teachers and supervisors are useful for them. 
The pedagogical implication of this research can be drawn. Teaching practicum can be a reflection for both teacher and student teachers in the classroom context and makes the student teachers be imaged of how they should behave when they become a real teacher. As all the participant stories show, the teachers' identity of the participants emerges through this teaching practicum. The participants also found some struggles that helped to shape their identities. Hence, they are ready to face every struggle that comes when they are be a teacher and teach in a formal school one day. Second, for the seasoned teachers, this study can be a reflection and knowledge for them to be more aware of what kind of learning that the students really want in the school. Several ways that the participants in this study, do are quite effective in grabbing the students' attention and enthusiastic learning in the class. From this study, seasoned teachers can adopt and adapt to their future learning in the class.

I acknowledged that more participants and more empirical evidence could be provided in future studies. For instance, a classroom observation study may be conducted to look at how the student teachers behave in the placement school. Engaging some seasoned teachers and students in the study also can give more data for future study. Qualitative research can be used to examine the engagement of student teachers to seasoned teachers and students in the placement school. This engagement is then related to the construction of their identity during the teaching practicum program.

\section{REFERENCES}

Alghamdy, R. Zannan. (2018). Pre-Service English Teachers' Perceptions, Obstacles, and Experiences When Teaching English in the EFL Context. Saudi Arabia. Canadian Center of Science and Education. Asian Social Science; Vol. 14, No. 8. DOI:10.5539/ass.v14n8Rahma02.

Al Sohbani, Yehia Ahmed. (2012). Prospective EFL Teachers' Perceptions of the Teaching Practice Experience at AUST. Arab World English Journal (AWEJ). Volume.3 Number.4, 2012, pp. 195 - 213. INTERNATIONAL PEER REVIEWED JOURNAL ISSN: 2229-9327.

Barkhuizen, G. (2014). Revisiting narrative frames: An instrument for investigating language teaching and learning. System 47 (2014) 12-27. Elsevier.

Barkhuizen, G., Benson, P., \& Chick, A. (2014). Narrative Inquiry in Language Teaching and Learning Research. New York: Routledge.

Beauchamp, Catherine \& Lynn Thomas. (2009). Understanding teacher identity: an overview of issues in the literature and implications for teacher education. Cambridge Journal of Education 39:2, 175-189. DOI: 10.1080/03057640902902252.

Castañeda-Trujillo, J. E., \& Aguirre-Hernández, A. J. (2018). Pre-service English teachers' voices about the teaching practicum. HOW, 25(1), 156-173. https://doi.org/10.19183/how.25.1.420. 
Chimhenga, Sylod. (2017). The Student Teachers' Perceptions On Teaching Practice Supervision In Zimbabwe: Is It A Process Of Grading Or Improvement of Teaching Skills?. INTERNATIONAL JOURNAL OF SCIENTIFIC \& TECHNOLOGY RESEARCH VOLUME 6, ISSUE 07, JULY 2017.

Creswell, J. W. (2012). Educational Research: Planning, Conducting and Evaluating Quantitative and Qualitative Research. Fourth Edition.

FAJARDO CASTAÑEDA, JOSÉ ALBERTO. (2013). What Makes a Teacher: identity and classroom talk. Cuadernos de Lingüística Hispánica, (22), 127146. Retrieved July 01, 2020, from http://www.scielo.org.co/scielo.php?script=sci_arttext\&pid=S0121$\underline{053 X 2013000200009 \& \operatorname{lng}=\text { en \& tlng=en. }}$

Johnson, K., \& Golombek, P. (Eds.). (2002). Teachers' Narrative Inquiry as Professional Development. Cambridge: Cambridge University Press.

Korkut, Perihan. (2017). Classroom Management in Pre-service Teachers' Teaching Practice Demo Lessons: A Comparison to Actual Lessons by Inservice English Teachers. Journal of Education and Training Studies. 5. 1. 10.11114/jets.v5i4.2164.

Liu, Yongcan \& Xu Yueting. (2010). Inclusion or exclusion? : A narrative inquiry of a language teacher's identity experience in the 'new work order' of competing pedagogies. Teaching and Teacher Education 27 (2011) 589-597. Elsevier.

Mahmoudia, Farzaneh, and Yonca Özkan. (2016). Practicum Stress and Coping Strategies of Pre-service English Language Teachers. Antalya, Turkey. Procedia - Social and Behavioral Sciences 232 (2016) 494-501. International Conference on Teaching and Learning English as an Additional Language, GlobELT 2016, 14-17 April 2016.

Merch, Ali. (2010). Self-Reported Problems of Pre-Service EFL Teachers throughout Teaching Practicum. ANADOLU UNIVERSITY JOURNAL OF SOCIAL SCIENCES. Cilt/Vol.: 10 - Say1/No: 2: 199-226 (2010).

Moore, B. (2017). In what way do teachers learn to use their identity to influence their classroom management?. DOI: 10.13140/RG.2.2.29425.53600

Permatasari, Dinda, Herri Mulyono, and Ferawati. (2019). Investigating the Contributing Factors to Teaching Anxiety during Teaching Practicum: A Case of Indonesian Pre-Service EFL Teachers. Indonesia. Jambi University, the Graduate School, Doctoral Program in Education. Indonesian Research Journal in Education (IRJE) Vol. 2 No. 2, the Year 2019. E-ISSN: 25805711.

Ragawanti, D.T. (2015). CULTIVATING PRE-SERVICE TEACHERS' CLASSROOM MANAGEMENT SKILLS THROUGH TEACHING PRACTICUM: A REFLECTIVE PRACTICE. TEFLIN Journal, Volume 25, Number 1, January 2015. 
Schepens, A., Antonia Aelterman \& Peter Vlerick. (2009). Student teachers' professional identity formation: between being born as a teacher and becoming one. Educational Studies. Vol 35:4, 361-378, DOI: 10.1080/03055690802648317.

Shalawati and Sitti Hadijah. (2018). Teaching Practicum Current Practices: Challenges and Opportunity. Riau, Indonesia. Journal of English for Academic. J-SHMIC, Vol. 5, No 1, February 2018.

Teng, F. (2019). A narrative inquiry of identity construction in academic communities of practice: voices from a Chinese doctoral student in Hong Kong. Pedagogies: An International Journal. DOI: 10.1080/1554480X.2019.1673164.

Timoštšuk, I., \& Ugaste, A. (2010). Student teachers' professional identity. Teaching and Teacher Education, 26(8), 1563-1570. DOI:10.1016/j.tate.2010.06.008.

Trent, J. (2010). Teacher education as identity construction: insights from action research. Journal of Education for Teaching, 36(2), 153-168. DOI: $10.1080 / 02607471003651672$.

Trent, John. (2013). From learner to teacher: practice, language, and identity in a teaching practicum. Asia-Pacific Journal of Teacher Education, 41:4, 426440. DOI: 10.1080/1359866X.2013.838621.

Trent, John. (2018). 'Fitting in' or 'being different'? Integration, separation, and identity construction during a teaching practicum in Hong Kong. Teacher Development. ISSN: 1366-4530 (Print) 1747-5120 (Online) Journal homepage: http://www.tandfonline.com/loi/rtde20. DOI:10.1080/13664530.2018.1466722.

Yanto, Elih, S., \& Pravitasari, Hikmah. (2020). A NARRATIVE INQUIRY OF STUDENT TEACHERS MULTIMODAL PRACTICE EXPERIENCES IN THE INDONESIAN ESP CLASSROOM CONTEXT. Wiralodra English Journal (WEJ). Vol.4 No.1.

Yusof, Normah et al. (2014). STUDENT TEACHERS PERCEPTION TOWARDS TEACHING PRACTICUM PROGRAMME. Kuala Terengganu, Malaysia. International Journal for Innovation Education and Research Vol.2-10, 2014. www.ijier.net.

Zhu, Gang. (2017). Chinese Student Teachers' Perspectives on becoming a teacher in the practicum: emotional and ethical dimensions of identity shaping. Journal of Education for Teaching, 43:4, 491-495. DOI: $10.1080 / 02607476.2017 .134116$

\section{BIO STATEMENT}

Devi Apriliani is a bachelor candidate in Universitas Singaperbangsa Karawang. Her major is English Education Department in the Faculty of Teachers Training and Education. She is taking English for Specific Purposes and Interpreting. She is interested in exploring perception linguistics. 